\title{
Location, sidedness, and sex distribution of incidental intracranial arachnoid cysts in childhood: An MRI study
}

\section{Çocukluk çağındaki rastlantısal intrakranyal araknoid kistlerin lokalizasyonu, yönü ve cinsiyet dağılımı: Bir MRG çalışması}

Mehmet Haydar Atalar ${ }^{1}$, Kayhan Karakuş ${ }^{1}$, Bülent Yıldız², İsmail Şallk ${ }^{2}$

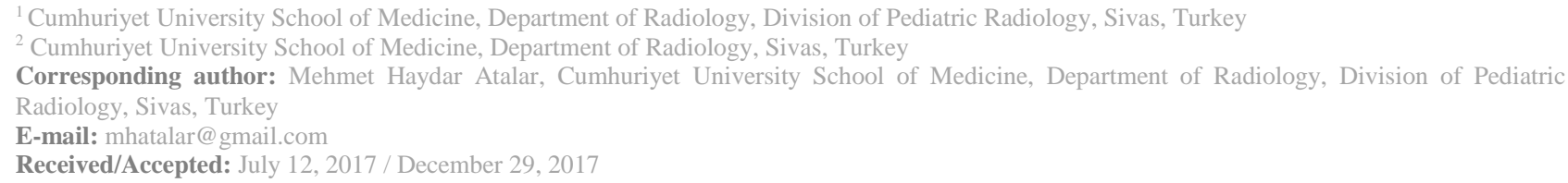

\section{SUMMARY}

Objective: The objective of this study was to evaluate retrospectively the MRI features of incidental intracranial arachnoid cysts with regard to their distribution of cyst location, sidedness, Galassi type, and gender in children during the workup for headache and seizures.

Method: MRI scans of the head performed from May 2005 to May 2015 were reviewed retrospectively to analyze arachnoid cysts detected incidentally in children.

Results: The mean ages of boys $(\mathrm{n}=63)$ and girls (36) were $8.4 \pm 5.0$ ( 2 months to 18 years) and $8.9 \pm 4.0$ (6 months to 14 years), respectively. Although the number of boys with left, right or midline sidedness was higher compared to girls, these differences were not reached statistical significance $(p>0.5)$. For both boys and girls, arachnoid cysts were located in middle cranial fossa, frontal convexity, and posterior fossa significantly more commonly than other locations. Overall, for all locations, the number of boys was greater compared to girls. Although the number of boys with Galassi types I, II, and III was greater compared to girls, these differences did not reach statistical significance.

Conclusions: In carefully selected patients, MRI provides information about presence and nature of arachnoid cysts that are otherwise impossible to detect clinically. Intracranial arachnoid cysts are one of the important incidental findings detected during the MRI of head. In an MRI report, the size, location, and other important features of arachnoid cysts need to be described in detail for the long-term follow-up and management of these benign lesions that are most commonly asymptomatic but may present with severe symptoms in some cases.

Keywords: Arachnoid cyst, children, intracranial, magnetic resonance imaging

\section{ÖZET}

Amaç: Bu çalışmanın amacı, rastlantısal intrakranyal araknoid kistlerin manyetik rezonans görüntüleme (MRG) özelliklerini, baș ağrısı ve nöbetler için yapılan çalışmalarda çocuklarda kist yeri, yönü, Galassi tipi ve cinsiyet dağılımı açısından retrospektif olarak değerlendirmektir.

Yöntem: Mayıs 2005 ile Mayıs 2015 arasında yapılan kranyal MRG taramaları, çocuklarda tesadüfen tespit edilen araknoid kistler açısından geriye dönük olarak incelendi.

Bulgular: Erkeklerin $(\mathrm{n}=63)$ ve kızların (36) yaș ortalaması $8.4 \pm 5.0$ (2 ay-18 yaș) ve $8.9 \pm 4.0$ (6 ay- 14 y1l) arasında değişmektedir. Erkeklerin say71sı, kızlara göre sağ, sol veya orta hat yanılgısına göre daha yüksek olmasına rağmen istatistiksel olarak anlamlı değildi ( $p>0.5)$. Hem erkek hem de kılar için, orta kranyal fossa, frontal konveksite ve posterior fossa diğer yerlerden anlamlı olarak daha yüksekti. Genel olarak, tüm bölgeler için, erkeklerin sayısı kızlara göre daha fazla idi. Galassi tip I, II ve III'e göre erkek çocuk sayısı kızlara göre daha yüksek olmasına rağmen, bu farklılıklara istatistiksel olarak anlamlı bir fark bulunamamışır. 
Sonuç: Dikkat çekici olarak seçilen hastalarda MRG, araknoid kistlerin varlığı ve doğası hakkında bilgi verir, aksi takdirde klinik olarak tespit edilemez. İntrakranyal araknoid kist, MRG sırasında saptanan önemli tesadüfî bulgulardan biridir. MRG raporunda, araknoid kistlerin büyüklüğü, yeri ve diğer önemli özellikleri, en yaygın olarak asemptomatik olan, ancak bazı durumlarda şiddetli semptomlarla ortaya çıkan benign lezyonların uzun vadeli takip ve yönetimi için detaylı olarak tanımlanmalıdır

Anahtar sözcükler: Araknoid kist, çocuk, intrakranyal, manyetik rezonans görüntüleme

\section{INTRODUCTION}

Arachnoid cysts are one of the frequent incidental findings in the cranium and spinal canal on neuroimaging studies. They are benign congenital malformations of the arachnoid mater ${ }^{1,2}$. Secondary arachnoid cysts are not as frequent as primary ones and are usually related to the head injury, meningitis, or tumors, or as a complication of brain surgery. They are actually intraarachnoid sacs without any communication with the ventricular system. Their content is generally a clear, colorless fluid resembling normal cerebrospinal fluid but they may also infrequently contain a xanthochromic fluid ${ }^{3,4}$. Arachnoid cysts have an unlimited ability to grow or recur, and it is not clear how they can produce fluid or grow in size $^{5}$. The development and expansion of arachnoid cysts may be caused by aberrant cerebrospinal fluid dynamics ${ }^{6}$. The natural history of the growth of arachnoid cysts is not clear, which leads to confusion in deciding treatment strategies of incidental, asymptomatic arachnoid cysts in children ${ }^{7}$.

Arachnoid cysts may cause specific symptoms, such as sensorimotor symptoms corresponding to the location of the cyst; however, they more often cause nonspecific symptoms such as headache or dizziness, or symptoms related to suboptimal cerebral function, such as epilepsy or impaired cognition ${ }^{8-15}$. Headache is a common problem in children and adolescents, affecting some 59\% of boys and $84 \%$ of girls within the age group of $13-$ 19 years ${ }^{16}$. While there is considerable parental concern that headache in their children is caused by an intra-cerebral space-occupying process, in reality, this is only rarely the case ${ }^{17-19}$. Wester ${ }^{20}$ stated that the introduction of CT has certainly lowered the threshold for performing radiological studies for the differential diagnosis of headache since the latter is the main symptom in patients with intracranial arachnoid cysts. In the CT and MRI era, the knowledge about the distribution of cyst location, sidedness, and sex in general population considerably increased. As stated by Alexiou and Argyropoulou in a recent review about the use of neuroimaging modalities in the differential diagnosis of pediatric headache, the diagnostic evaluation and workup of headache is very challenging for pediatricians, and CT or MRI investigation is often requested as part of the diagnostic workup. Radiation is an important disadvantage of CT, while MRI is costly and sometimes requires sedation or general anesthesia, especially in children younger than 6 years ${ }^{17-21}$.

With the continuing advances in neuroimaging, detection of arachnoid cysts has become widespread at earlier ages in patients with or without symptoms ${ }^{22}$. According to our literature review, there is a considerably small body of knowledge related to CT or MRI findings of arachnoid cysts in children to shed light on the differential diagnosis of pediatric headache.

The aim of this study was to analyze retrospectively the MR imaging features of incidental intracranial arachnoid cysts with regard to the distribution of cyst location, sidedness, Galassi type, and sex among children referred for the differential diagnosis of headache and seizures.

\section{MATERIAL AND METHODS}

In this study, 99 MRI scans of the head performed at our Radiology Service from May 2005 to May 2015 were reviewed retrospectively to analyze arachnoid cysts detected incidentally in children who had undergone MRI to make a differential diagnosis of headache, seizure, learning disabilities, and attention deficit. We investigated 99 patients with 99 intracranial cysts.

\section{MR examinations}

MR examinations were performed using a 1.5 Tesla MR scanner (Excelart, Toshiba, Tokyo, Japan) using standard head coils. The MRI examination included axial and sagittal spin-echo (SE) T1-weighted [repetition time (TR) $550 \mathrm{~ms}$, echo time (TE) $15 \mathrm{~ms}$, flip angle $90^{\circ}$ ], axial and coronal fast SE (FSE) T2-weighted (TR $5000 \mathrm{~ms}$, TE $94 \mathrm{~ms}$, flip angle $90^{\circ}$ ), and axial fluidattenuated inversion recovery (FLAIR; TR 7500 ms, TE 94 ms, TI 2200, flip angle $90^{\circ}$ ) images. No contrast material was used in MRI examinations. Arachnoid cysts were easily detected with the help of signal similarity with the cerebrospinal fluid at T2-weighted sequences. All MRI scans were reviewed by qualified radiologists.

In these cases, arachnoid cysts were most commonly found in the middle cranial fossa. 
According to the well-known classification system by Galassi et al. ${ }^{23}$, arachnoid cysts located in the middle cranial fossa are categorized into three types: type I cysts, located in the sylvian fissure, posterior to the sphenoid ridge, causing no mass effect, and freely communicating with the subarachnoid space; type II cysts, found as larger, rectangular lesions, located at proximal and middle part of the sylvian fissure and slowly communicating with the subarachnoid space; and type III cysts, found as the largest and lenticular shaped lesions generally causing midline shift but no communication with the subarachnoid space ${ }^{24}$ (Figures 1-5).

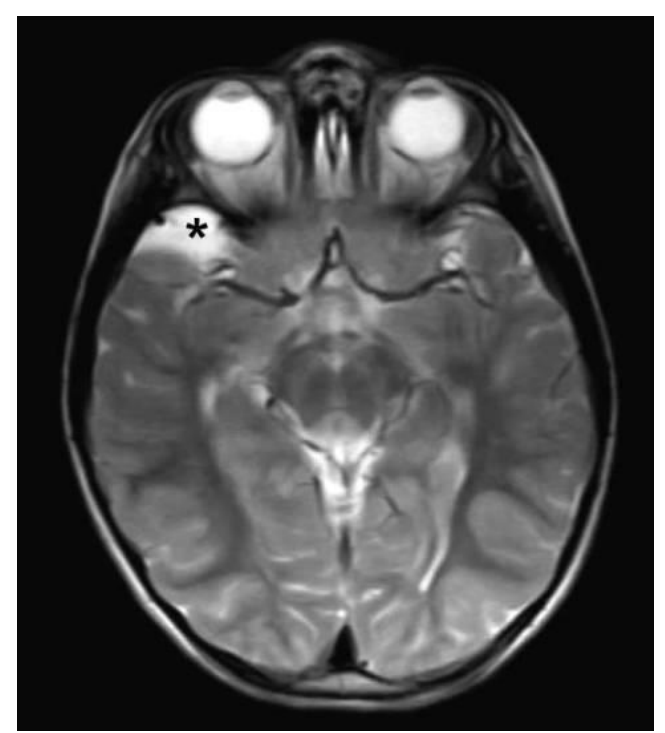

Figure 1. A 3-year-old-girl. Axial T2-weighted MR image shows Galassi type I arachnoid cyst in the right middle cranial fossa (asterix).

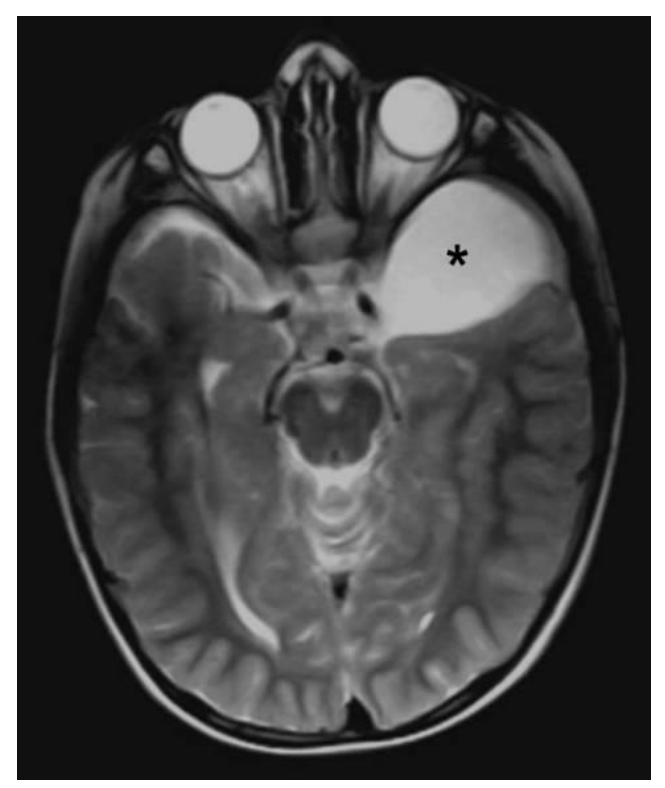

Figure 2. A 5-year-old girl. Axial T2-weighted MR image shows Galassi type II arachnoid cyst in the left middle cranial fossa (asterix). 


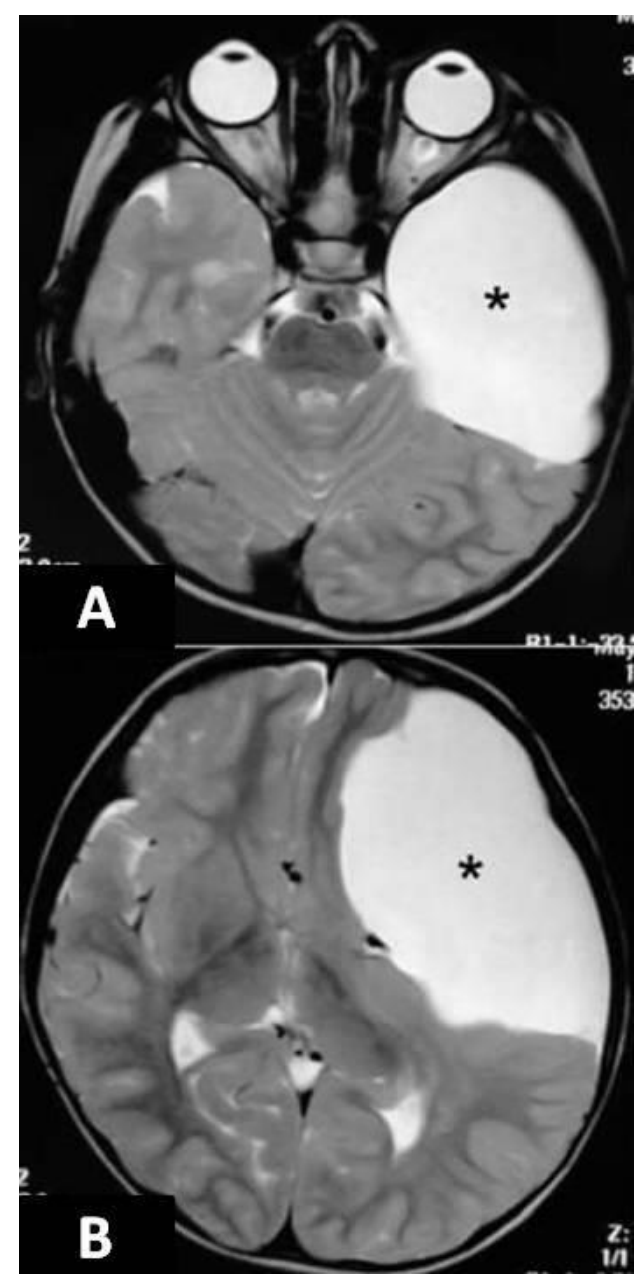

Figure 3. A 10-year-old boy. (A, B) Axial T2-weighted MR images show Galassi type III arachnoid cyst in the right middle cranial fossa extending to the left frontal region (asterix).

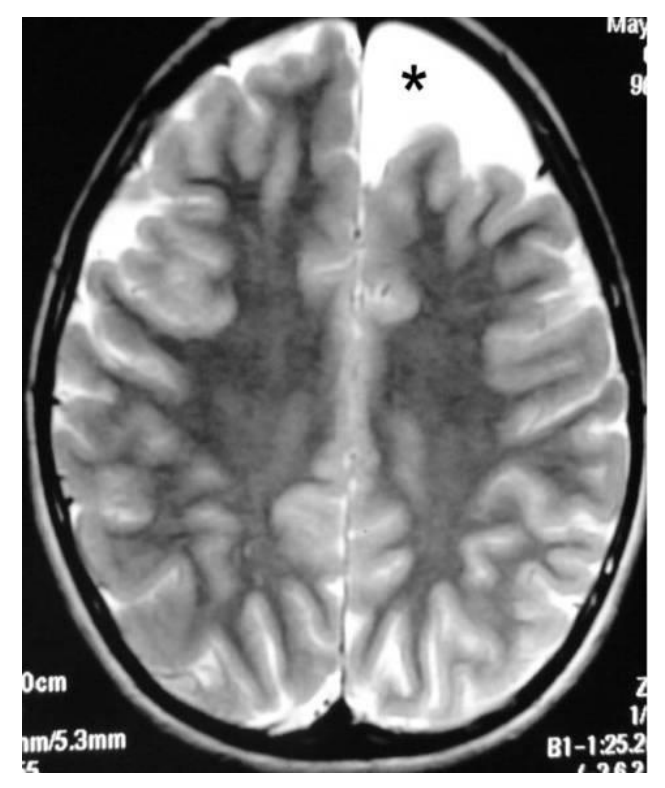

Figure 4. A 6-year-old boy. Axial T2-weighted MR image shows arachnoid cyst in the left frontal convexity (asterix). 


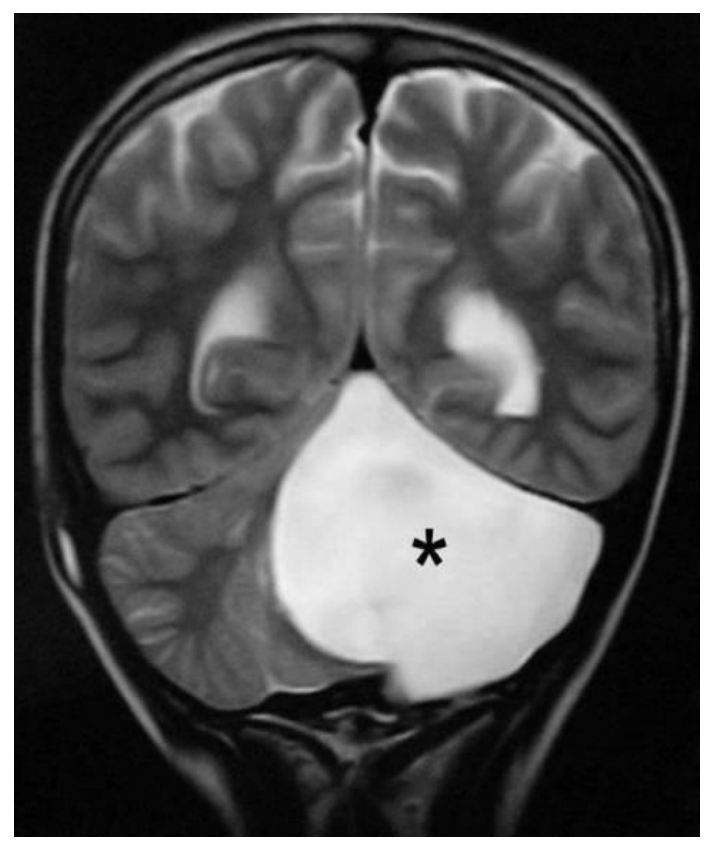

Figure 5. A 4-year-old boy. Coronal T2-weighted MR image shows a large arachnoid cyst in the left posterior fossa (asterix).

\section{Statistical analysis}

We recorded MRI data related to the cyst location, sidedness, Galassi type (for only middle cranial fossa), and sex of the cases with arachnoid cyst. Cases ( $n=99)$ were divided into gender subgroups. Data were expressed as number and percentage. MRI data were analyzed with the Chi-square test. Statistical significance was set at $\mathrm{p}<0.05$ level.

\section{RESULTS}

The 99 study subjects had 99 intracranial arachnoid cysts. The mean ages of boys $(n=63)$ and girls (36) were $8.4 \pm 5.0$ ( 2 months to 18 years) and $8.9 \pm 4.0$ (6 months to 14 years), respectively.

Figure 6 presents the number of boys and girls according to sidedness. Although the number of boys with left, right or midline sidedness was higher compared to girls, these differences were not reached statistical significance.

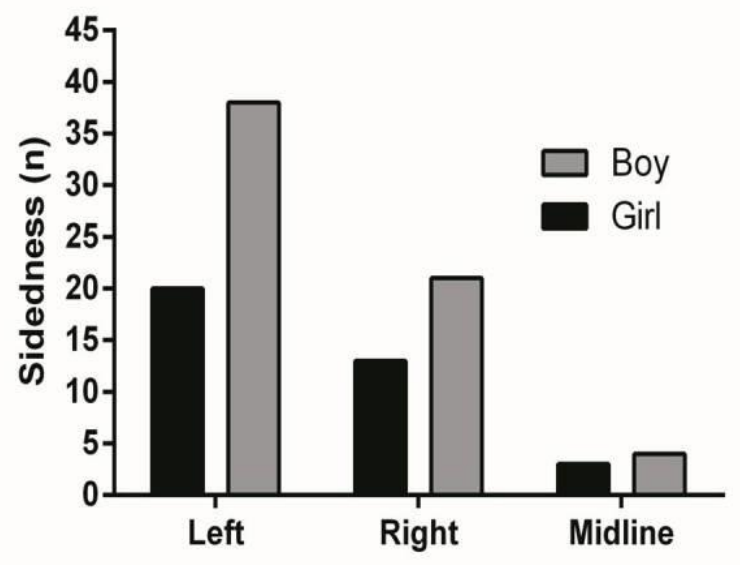

Figure 6. Number of boys and girls by sidedness.

Figure 7 shows the distributions of intracranial arachnoid cysts of boys and girls according to location in the study population. For both boys and girls, arachnoid cysts were located in middle cranial fossa, frontal convexity, and posterior fossa significantly more commonly than other locations. Overall, for all locations, the number of boys was greater compared to girls. 


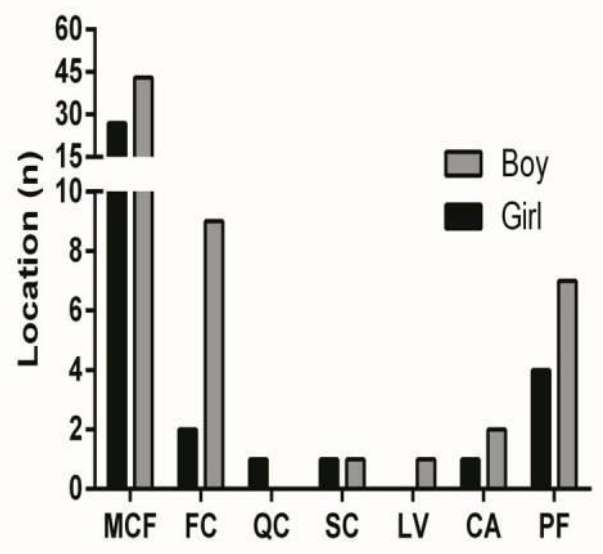

Figure 7. Distributions of intracranial arachnoid cysts of boys and girls by location. MCF, middle cranial fossa; FC, frontal convexity; QC, quadrigeminal cistern; SC, supracellar cistern; LV, lateral ventricle; CA, cerebellopontine angle; and $\mathrm{PF}$, posterior fossa.

Figure 8 presents the distribution of temporal arachnoid cysts in boys and girls according to Galassi classification. Although the number of boys with Galassi types I, II, and III was greater compared to girls, these differences did not reach statistical significance.

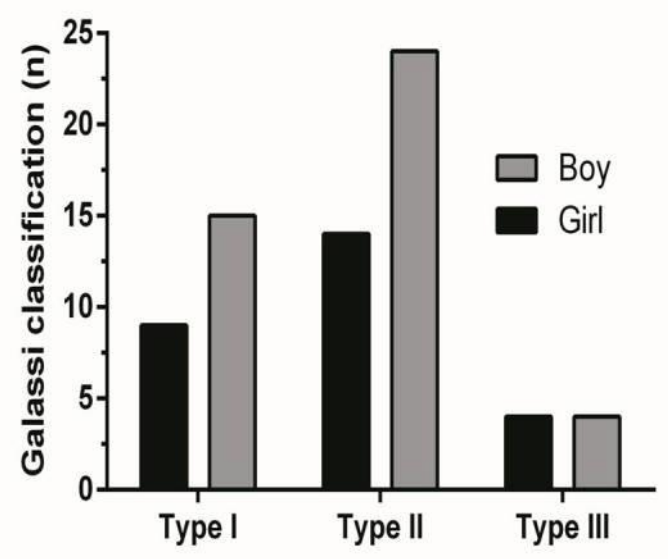

Figure 8. Distribution of temporal arachnoid cysts in boys and girls by Galassi classification.

\section{DISCUSSION}

In this series, we presented MRI findings of 63 boys and 36 girls aged from 2 months to 18 years. We observed that the numbers of boys in all sidedness subgroups was greater than girls. With regard to the location, middle cranial fossa was significantly more common in both boys and girls, followed by middle cerebral fossa, posterior fossa, and frontal convexity. Other locations were found in small numbers. Because of small case numbers in subgroups, we could not detect statistical differences between the many subgroups with regard to several parameters in chi-square analysis, as one would expect. Although there was no cases with multiple arachnoid cysts, Koc et al. ${ }^{25}$ reported an adult case with multiple arachnoid cysts classified as Galassi types II and III causing intermittent headache.

According to Galassi classification, arachnoid cyst type 1 is small, spindle shaped and located in the middle cranial fossa; arachnoid cyst type 2 extends along sylvian fissure and displaces the temporal lobe; and the type 3 not only displaces the temporal lobe but also the parietal lobe and fills entire middle cranial fossa ${ }^{5}$. As for the arachnoid cysts located in the middle cranial fossa classified according to Galassi classification, arachnoid cysts type II are more common, followed by type I and then type III. The male-to-female ratio was similar in the subgroups created by the Galassi classification. 
Overall, boys were more numerous in all types except for the type III, where. There were equal numbers of boys and girls.

Arachnoid cysts are benign intra-arachnoid collections of cerebrospinal fluid; they are mostly congenital in origin, and account for about $1 \%$ of all atraumatic intracranial mass lesions. They cause neurological deficit through expansion, compression of normal neural tissue, and obstruction of cerebrospinal fluid flow. They usually arise in areas that are rich in arachnoid mater, and 50\% are located in the Sylvian fissure. Symptoms depend on lesion size and location. Seizures and headache are said to be the most common symptoms of middle cranial fossa cysts. The definitive treatment for arachnoid cysts is surgery, the most common indications of which are the presence of progressive hydrocephalus and intracranial hypertension ${ }^{26}$.

Wester ${ }^{20}$ retrospectively evaluated the distribution of intracranial arachnoid cysts with respect to location, sidedness, and gender. They found that arachnoid cysts had a clear affinity for the middle fossa $(65.2 \%)$; that the left-sidedness of middle fossa cysts was found only in males; that middle fossa cysts occurred more than four times as often in males; and that cysts in all other intracranial locations did not reveal similar affinities for any sex or side. They noted that since the symptoms most commonly associated with arachnoid cysts were fluctuating and relatively nondramatic; the diagnosis was often established late (in their study, median age 28 years). Helland et al. ${ }^{27}$ retrospectively analyzed 156 adult cases with subarachnoid cysts that had undergone surgical cyst decompression. They found that arachnoid cysts were located in temporal fossa (left $49.4 \%$, right $21.2 \%$, and bilateral $1.9 \%$ ), frontal (left $5.1 \%$ and right $10.3 \%$ ), posterior fossa (left $0.6 \%$, right $3.2 \%$, and midline $4.5 \%$ ), and other locations $(3.8 \%)$. Overall, they suggested that decompression of arachnoid cysts provides a substantial clinical benefit with a low risk of severe complications. Later, Helland et al. ${ }^{28}$ reevaluated a higher number of intracranial arachnoid cysts. They noted that temporal cysts occurred more frequently in men, and CPA cysts are more frequently found in women.

There is a continuing debate about the predilection of arachnoid cysts for the middle fossa $8,20,23,26,29$ ${ }^{31}$. Wester ${ }^{20}$ presented a new hypothesis on the genesis of intracranial arachnoid cysts. $\mathrm{He}$ postulated that at the site of contact of two arachnoid membranes, an encapsulated cyst is trapped between the two membranes. Contrary to former point of view, the arachnoid membrane has been found to be split to enclose the cyst, with only a single compressed subarachnoid space beneath the arachnoid cyst. He suggested a theory that may explain how mal-development of the leptomeninges may contribute to the formation of arachnoid cysts, and why such cysts are more common in the temporal fossa.

Erdincler et al. ${ }^{32}$ presented a case series of 12 adult patients with posterior fossa arachnoid cysts diagnosed with CT or MRI. They noted that surgical treatment provides good clinical success with regard to symptomatology and recurrence. Marin-Sanabria et al. ${ }^{33}$ retrospectively analyzed 112 patients with arachnoid cysts of posterior fossa. Of their cases, $23(20.5 \%)$ were symptomatic. They performed surgical treatment and noted that surgical modalities provide variable success, depending on the clinical presentation. There are controversial aspects of surgical management of arachnoid cysts in children ${ }^{34}$. Craniotomy for cyst fenestration has been recommended to reduce morbidity and mortality and making a child shunt-independent. Depending to their clinical experience with 66 cases with arachnoid cysts (44 [67\%] were located in the middle cranial fossa), Kang et al. ${ }^{34}$ concluded that radical excision of the outer and inner membranes of the cyst wall with fenestration into the basal cistern is a safe and effective shunt-independent procedure for arachnoid cysts of middle cranial fossa, especially for those of types I and II (Galassi classification). They noted that on follow-up CT scan and MRI, cysts of type I and II exhibited a steady tendency to reduction or obliteration.

Fewel et al. ${ }^{35}$ presented their experience with the management of 95 children with intracranial arachnoid cysts. In their cases, mean age of presentation was 4.9 years (ranging from 3 days to 7.8 years). They noted that the presence of hydrocephalus is an important determinant of longterm success of surgery. They recommended cyst fenestration, but with a ventriculoperitoneal shunt inserted before fenestration if the hydrocephalus is marked or after fenestration if the hydrocephalus is progressive. Lee and $\mathrm{Ra}^{36}$ analyzed long-term clinical and neuroimaging results of surgically treated intracranial cysts in 110 pediatric patients. They performed endoscopic cyst fenestration in 71 cases, while craniotomy and cyst excision (with or without fenestrations) were spared for 30 patients. Nine of their patients required cystoperitoneal shunts. They found that clinical and radiological improvement was between $85.7 \%$ and $100 \%$, depending on the type of arachnoid cyst and the surgical modality. Zada et al. ${ }^{6}$ investigated the 
clinical presentation and management of arachnoid cysts in babies less than 2 years old. They noted that in many cases there was macrocephaly that required stunting procedure more frequently than the patients with seizures or incidental lesions. Recent advances in neurosurgical techniques and neuroendoscopy continue to favor fenestration over shunt insertion as the method of choice for initial cyst decompression ${ }^{22}$. Ozek and Urgun ${ }^{37}$ presented their experience with the management of 34 cases of suprasellar-prepontine arachnoid cysts. They noted that surgical management of suprasellar arachnoid cysts could be accomplished with endoscopic interventions with favorable clinical and radiological results.

\section{CONCLUSION}

According to the findings of our study, in carefully selected patients MRI provides information about presence and nature of arachnoid cysts, which are otherwise non-detectable clinically. Intracranial arachnoid cysts are among the important incidental findings detected during the MRI of head. In MRI report, the size, location, and other important features of arachnoid cysts need to be described in detail for the long-term follow-up and management of these benign lesions but may present with severe symptoms in some cases.

\section{REFERENCES}

1. Chen CP. Prenatal diagnosis of arachnoid cysts. Taiwan J Obstet Gynecol. 2007; 46(3):187-98.

2. Patel TR, Bannister CM, Thorne J. A study of prenatal ultrasound and postnatal magnetic imaging in the diagnosis of central nervous system abnormalities. Eur J Pediatr Surg. 2003; 13 Suppl 1:S18-22.

3. Pascual-Castroviejo I, Roche MC, Martínez Bermejo A, Arcas J, GarcíaBlázquez $M$. Primary intracranial arachnoidal cysts. A study of 67 childhood cases. Childs Nerv Syst. 1991;7(5):257-63.

4. Khan AN. Arachnoid Cyst Imaging. Available at: www.medscape.com. Accessed on: October 2013.

5. Catala M, Poirier J. [Arachnoid cysts: histologic, embryologic and physiopathologic review]. Rev Neurol (Paris). 1998; 154(67):489-501.

6. Zada G, Krieger MD, McNatt SA, Bowen I, McComb JG. Pathogenesis and treatment of intracranial arachnoid cysts in pediatric patients younger than 2 years of age. Neurosurg Focus.
2007;22(2):E1.

7. Lee JY, Kim JW, Phi JH, Kim SK, Cho BK, Wang KC. Enlarging arachnoid cyst: a false alarm for infants. Childs Nerv Syst. 2012; 28(8):1203-11

8. Murthy JM. Intracranial arachnoid cysts: Epileptic seizures. Neurol India. 2013; 61(4):343-4.

9. De Volder AG, Michel C, Thauvoy C, Willems G, Ferrière G. Brain glucose utilisation in acquired childhood aphasia associated with a sylvian arachnoid cyst: recovery after shunting as demonstrated by PET. J NeurolNeurosurg Psychiatry. 1994; 57(3):296-300.

10. Colameco S, DiTomasso RA. Arachnoid cyst associated with psychological disturbance. J Med Soc N J. 1982; 79(3):209-10.

11. Lang W, Lang M, Kornhuber A, Gallwitz A, Kriebel J. Neuropsychological and neuroendocrinological disturbances associated with extracerebral cysts of the anterior and middle cranial fossa. Eur Arch Psychiatry Neurol Sci. 1985; 235(1):38-41.

12. Albuquerque FC, Giannotta SL. Arachnoid cyst rupture producing subdural hygroma and intracranial hypertension: case reports. Neurosurgery. 1997; 41(4):951-5; discussion 955-6.

13. Thinakara-Rajan $T$, Janjua A, Srinivasan V. Posterior fossa arachnoid cyst presenting with isolated sensorineural hearing loss. J Laryngol Otol. 2006; 120(11):979-82.

14. Raeder MB, Helland CA, Hugdahl K, Wester K. Arachnoid cysts cause cognitive deficits that improve after surgery. Neurology. 2005; 64(1):160-2.

15. Wester K, Hugdahl K. Verbal laterality and handedness in patients with intracranial arachnoid cysts. J Neurol. 2003; 250(1):36-41.

16. Zwart JA, Dyb G, Holmen TL, Stovner LJ, Sand $\mathrm{T}$. The prevalence of migraine and tension-type headaches among adolescents in Norway. The Nord-Trøndelag Health Study (Head-HUNTYouth), a large population-based epidemiological study. Cephalalgia. 2004; 24(5):373-9.

17. Martens D, Oster I, Gottschlling S, Papanagiotou P, Ziegler K, Eymann R, Ong MF, Gortner L, Meyer S. Cerebral MRI and EEG studies in the initial management of pediatric headaches. Swiss Med Wkly. 2012; 
142:w13625.

18. Abu-Arafeh I, Macleod S. Serious neurological disorders in children with chronic headache. Arch Dis Child. 2005; 90(9):937-40.

19. Alexiou GA, Argyropoulou MI. Neuroimaging in childhood headache: a systematic review. PediatrRadiol. 2013; 43(7):777-84.

20. Wester K. Peculiarities of intracranial arachnoid cysts: location, sidedness, and sex distribution in 126 consecutive patients. Neurosurgery. 1999; 45(4):775-9.

21. Ozge A, Termine $C$, Antonaci F, Natriashvili $S$, Guidetti V, Wöber-Bingöl C. Overview of diagnosis and management of paediatric headache. Part I: diagnosis. J Headache Pain. 2011; 12(1):13-23.

22. Pradilla G, Jallo G. Arachnoid cysts: case series and review of the literature. Neurosurg Focus. 2007; 22(2):E7.

23. Galassi E, Tognetti F, Gaist G, Fagioli L, Frank F, Frank G. CT scan and metrizamide CT cisternography in arachnoid cysts of the middle cranial fossa: classification and pathophysiological aspects. Surg Neurol. 1982; 17(5):363-9.

24. Yildiz H, Erdogan C, Yalcin R, Yazici Z, Hakyemez B, Parlak M, Tuncel E. Evaluation of communication between intracranial arachnoid cysts and cisterns with phase-contrast cine MR imaging. AJNR Am J Neuroradiol. 2005; 26(1):145-51.

25. Koc G, Altay C, Bozkurt T, Varer M, Oyar O. Multiple intracranial arachnoid cysts. JBRBTR. 2012; 95(5):339.

26. Gelabert-González M. [Intracranial arachnoid cysts]. Rev Neurol. 2004; 39(12):1161-6.

27. Helland CA, Wester K. A population based study of intracranial arachnoid cysts: clinical and neuroimaging outcomes following surgical cyst decompression in adults. $\mathrm{J}$ NeurolNeurosurg Psychiatry. 2007; 78(10):1129-35.

28. Helland CA, Lund-Johansen M, Wester K. Location, sidedness, and sex distribution of intracranial arachnoid cysts in a populationbased sample. J Neurosurg. 2010; 113(5):9349.

29. Geschwind N, Galaburda AM. Cerebral lateralization. Biological mechanisms, associations, and pathology: I. A hypothesis and a program for research. Arch Neurol. 1985;
42(5):428-59.

30. Go KG, Houthoff HJ, Blaauw EH, Havinga P, Hartsuiker J. Arachnoid cysts of the sylvian fissure. Evidence of fluid secretion. $\mathrm{J}$ Neurosurg. 1984; 60(4):803-13.

31. Rengachary SS, Watanabe I. Ultrastructure and pathogenesis of intracranial arachnoid cysts. $\mathbf{J}$ NeuropatholExp Neurol. 1981; 40(1):61-83.

32. Erdincler P, Kaynar MY, Bozkus H, Ciplak N. Posterior fossa arachnoid cysts. Br J Neurosurg. 1999 ;13(1):10-7.

33. Marin-Sanabria EA, Yamamoto $H$, Nagashima T, Kohmura E. Evaluation of the management of arachnoid cyst of the posterior fossa in pediatric population: experience over 27 years. Childs Nerv Syst. 2007; 23(5):535-42.

34. Kang JK, Lee KS, Lee IW, Jeun SS, Son BC, Jung CK, Park YS, Lee SW. Shunt-independent surgical treatment of middle cranial fossa arachnoid cysts in children. Childs Nerv Syst. 2000; 16(2):111-6.

35. Fewel ME, Levy ML, McComb JG. Surgical treatment of 95 children with 102 intracranial arachnoid cysts. PediatrNeurosurg. 1996; 25(4):165-73.

36. Lee EJ, Ra YS. Clinical and neuroimaging outcomes of surgically treated intracranial cysts in 110 children. J Korean Neurosurg Soc. 2012; 52(4):325-33.

37. Ozek MM, Urgun K. Neuroendoscopic management of suprasellar arachnoid cysts. World Neurosurg. 2013; 79(2 Suppl): S19.e13-8. 